\title{
PIOSENKA POMOŻE NA WIELE, CZYLI O ALTERNATYWNYCH SPOSOBACH KSZTALTOWANIA KOMPETENCJI GRAMATYCZNEJ
}

\author{
Słowa kluczowe: strategia, ludyczność, glottodydaktyka, piosenki, repatrianci
}

Streszczenie. Artykuł porusza kwestię wykorzystywania piosenek na lekcjach jpjo jako realizację strategii ludycznej. Przedstawia sposoby wprowadzania pracy z tego rodzaju materiałem dydaktycznym w zakresie zagadnień gramatycznych. Prezentuje przykładowe zadania pozwalające doskonalić umiejętności językowe studentów. Dowodzi, że piosenka popularna jest stałym elementem otoczenia, a tym samym uniwersalnym narzędziem nauczania.

\section{ROLA PIOSENEK W NAUCZANIU JPJO}

Piosenka stanowi jeden z filarów kultury, nie tylko tej popularnej, masowej, ale również wysokiej. W świadomości Polaków jej rola została ukształtowana dzięki takim utworom jak: Piosenka jest dobra na wszystko z Kabaretu Starszych Panów oraz Śpiewać każdy może z repertuaru Jerzego Stuhra. Stanowi ona swoiste remedium na wszelkie niepowodzenia, a korzystanie z jej leczniczego działania - zarówno bierne, jak i czynne - dostępne jest dla wszystkich odbiorców kultury.

Celem artykułu jest przedstawienie konkretnych możliwości kształtowania kompetencji gramatycznej ${ }^{1}$ wśród osób uczących się języka polskiego jako obcego, drugiego, odziedziczonego na podstawie tekstów popularnych piosenek. Jednocześnie pojawia się pytanie, czy stosowanie takiej strategii w ramach metod ludycznych jest uniwersalne, to znaczy, czy jest to element, który można wykorzystać w każdej grupie.

*paulina.b.kazmierczak@gmail.com; Uniwersytet Łódzki, Wydział Filologiczny, Instytut Filologii Polskiej i Logopedii, Zakład Lingwistyki Stosowanej i Kulturowej, ul. Pomorska 171/173, 90-236 Łódź, ORCID: 0000-0002-6980-5988.

${ }^{1}$ Rozumianej jako umiejętność konstruowania wyrażeń oraz zdań zgodnie z zasadami gramatyki oraz zdolność ich odczytywania i rozumienia (Seretny, Lipińska 2005, s. 112-113). 
Wykorzystanie piosenek na lekcji języka obcego uważam bowiem za rodzaj strategii. Warto zauważyć, że popularyzacja terminu strategia to efekt badań nad problematyką przyswajania wiedzy (bezpośrednie strategie kognitywne), planowania procesu uczenia się (pośrednie strategie metakognitywne) oraz tworzenia atmosfery sprzyjającej rozwojowi uczniów i umożliwiającej im korzystanie z pomocy (pośrednie strategie socjo-afektywne) (Siek-Piskozub 2007, s. 13). Zgodnie $\mathrm{z}$ definicją, strategia to „szereg następujących po sobie operacji składających się z różnych technik uczenia" (Pfeiffer 2001, s. 105). Efektem wykonywanych działań powinno być osiągnięcie celu dydaktycznego (Rapacka-Wojtala 2015, s. 80). Jednak nie zawsze uczący się musi dostrzegać założenia nauczyciela, dotyczące na przykład doskonalenia kompetencji gramatycznej. W przypadku strategii ludycznej dążeniem ucznia staje się bowiem samo doświadczenie zabawy (Siek-Piskozub 2007, s. 14). To właśnie ostatni aspekt - odwołujący się do jednej z pierwotnych potrzeb człowieka - sprawia, że omawiane podejście można określić jako uniwersalne narzędzie dydaktyczne. Uczestnik zabawy doświadcza ryzyka związanego ze zwycięstwem lub przegraną oraz z weryfikacją zdolności intelektualnych i zręcznościowych. To moment, w którym gracz może się opowiedzieć za określonymi zasadami moralnymi wynikającymi z reguł gry. Istotnymi cechami zabawy są: swoboda działania, alternatywna - bowiem stworzona na potrzeby rozgrywki, a tym samym odmienna wobec codzienności i często będąca jej symulacją - rzeczywistość, a także ograniczenie czasu i przestrzeni (Huizinga 1998, s. 12-28). Związek nauki i zabawy jest zatem nie tylko formalny - ze względu na określone ramy i zasady postępowania - ale także semantyczny. Definicje tak gry, jak i zabawy uwzględniają potrzebę naśladowania wzorców i przygotowania do funkcjonowania w sytuacjach, jakie mogą mieć miejsce w prawdziwym życiu (por. m. in. Huizinga 1998, s. 12 oraz Stownik języka polskiego PWN, wyd. internetowe).

Wielopłaszczyznowe wykorzystanie piosenki sprawia, że omawiana strategia sprawdza się w różnych grupach wielokulturowych i polonijnych, wśród dzieci, dorosłych, niezależnie od poziomu biegłości językowej.

Jednym ze sposobów personalizacji programu nauczania jest stosowanie piosenek dopasowanych do omawianej podczas zajęć tematyki oraz do potrzeb grupy, a także konstruowanie zadań aktywizujących słuchaczy i pozwalających holistycznie pogłębiać ich kompetencje (Siek-Piskozub, Wach 2013, s. 238-239). Warto zaznaczyć, że praca z materiałami angażującymi różne style odbioru - wzrok, słuch, dotyk - oraz skłaniającymi do ruchu, wykonywania gestów, zwiększa szansę na sukces dydaktyczny w uczeniu kinestetyków, których potrzeby są często pomijane w procesie kształcenia (Dawidziak-Kładoczna 2008, s. 37-39). 


\section{WPLYW PIOSENEK NA PERCEPCJE UCZNIA}

Znalezienie materiałów muzycznych, zwiększających atrakcyjność lekcji, przysparza lektorom wielu kłopotów. Pomoc mogą stanowić źródła internetowe, na przykład forum metodyczne dla nauczycieli języka polskiego jako obcego, które znajduje się na stronie krakowskiej szkoły językowej Glossa. Jednym z poruszanych tam wątków jest wykorzystanie różnych piosenek na lekcjach jpjo. Użytkownicy proponują konkretne piosenki i wskazują zagadnienia gramatyczne, które można dzięki nim ćwiczyć. Utwory umożliwiają m. in. doskonalenie umiejętności stosowania różnych czasów i trybów, np.: Będziesz moja paniqa Marka Grechuty (czas przyszły złożony); Do kołyski zespołu Dżem (tryb rozkazujący). Nie brakuje także propozycji wspomagających ćwiczenie deklinacji: Na catych jeziorach - ty w wykonaniu Teresy Tutinas (miejscownik); Moje miasto Marii Peszek (dopełniacz)

Oprócz inspiracji internetowych na uwagę zasługują również podręczniki, w których coraz częściej korzysta się z materiałów audio. Przykładami są: Polski mniej obcy Agnieszki Madei i Barbary Morcinek-Cudak, Śpiewajaco po polsku Anny Majkiewicz i Jolanty Tambor, a także Księżyc w butonierce oraz To samo stońce Ewy Lipińskiej.

\subsection{WYKORZYSTANIE PIOSENEK Z BAJEK DLA DZIECI}

Wpływ muzyki na zrozumienie innych obyczajów, a tym samym proces akulturacji, jest często niedoceniany i pomijany (Pałasz 2013, s. 354-355). Sposobem na połączenie dwóch odległych systemów jest zastosowanie materiału dydaktycznego, który pełniłby funkcję swoistego mediatora między kulturą rodzimą studenta a nabywaną - polską. Taką rolę mogą odegrać piosenki z bajek zekranizowanych przez Walta Disneya. Produkcje zyskały bowiem światową sławę. Ich konstrukcja powoduje, że bawią nie tylko dzieci, ale także dorosłych. Stosowanie na lekcji pochodzących z kreskówek piosenek w polskiej wersji językowej przywołuje skojarzenia z dzieciństwem i beztroską, co stwarza atmosferę sprzyjającą doskonaleniu umiejętności lingwistycznych. Podczas zajęć warto skorzystać z dwóch rodzajów nagrań. Pierwsze słuchanie dobrze przeprowadzić w połączeniu z obrazem, który ułatwi

\footnotetext{
${ }^{2}$ Teksty wszystkich piosenek wymienionych w artykule można znaleźć na stronie www.tekstowo.pl [26.05.2018].

${ }^{3}$ Propozycje zaczerpnięte $\mathrm{z}$ forum internetowego dla nauczycieli jpjo, które jest dostępne pod adresem: www.e-polish.eu/forum-metodyczne-dla-nauczycieli-jezyka-polskiego-jako-obcego/piosenki [26.05.2018].
} 
zrozumienie treści, co wiąże się z wyświetleniem fragmentu bajki z polskim dubbingiem. W przypadku drugiego można posłużyć się nagraniami Studia Accantus znalezionymi w serwisie YouTube ${ }^{4}$. Piosenki w polskiej wersji językowej wykonywane są przez aktorów i wokalistów, którzy profesjonalnie zajmują się śpiewem. Dlatego dodatkową zaletą jest fakt, iż uczniowie mogą obserwować ruchy warg osób wykonujących utwory, co z pewnością ułatwi właściwą artykulację oraz wspólne zaśpiewanie piosenki, będące finalnym elementem pracy z tym materiałem.

Poniżej zaprezentowano propozycje zadań z wykorzystaniem piosenek: Nowe dni z filmu Zaplątani (koniugacje) ${ }^{5}$ oraz Kolorowy wiatr z kreskówki Pocahontas (biernik). Zostają one wprowadzone po uprzednim wysłuchaniu nagrań. Najczęściej w literaturze przedmiotu i propozycjach metodycznych odnaleźć można zadania, które polegają na uzupełnianiu luk w tekście. Jednak nie jest to jedyny typ ćwiczeń związanych z liryczną warstwą muzyki popularnej. Ich celem może być stworzenie wypowiedzi pisemnej motywowanej treścią utworu. Tak dzieje się w zadaniu pierwszym. Prowadzi to do utrwalenia form gramatycznych, np. odmiany czasowników przez osoby, a także rozwija kreatywność. Najpierw uczniowie analizują czynności wymienione w tekście piosenki i wykorzystują je do stworzenia planu dnia bohaterki. Następnie konstruują własny przebieg zajęć. W grupach, które są szczególnie uzdolnione muzycznie, można zaproponować napisanie planu-piosenki i zaśpiewanie go. Zadanie dostosowane jest do zajęć na poziomie A1/A2.

Zadanie 1. (Nowe dni) Praca indywidualna.

Proszę ułożyć plan dnia bohaterki na podstawie tekstu piosenki. Proszę napisać własny plan dnia.

Kiedy o siódmej dzień już na dobre wstanie, Muszę się zbierać, zajęć mnie czeka sto.

Sprzątam, woskuję, myję i robię pranie.

Zmiatam kurz, a to już robi się kwadrans po.
Coś tam ułożę, rzucę i wyjmę z pieca, papier mache, piruet i mat jak nic. Lepię naczynia, milczę i robię świece, Tutaj skłon, tutaj krąg, pnę się wzwyż, lubię szyć.

Następna propozycja dotyczy sprawdzenia umiejętności posługiwania się rzeczownikami w bierniku. W tekście są luki, które należy uzupełnić właściwymi formami tak, by stworzyć nową piosenkę. Zadanie nie tylko kształtuje kompetencję gramatyczną, ale także szeroko pojętą świadomość językową, konieczny jest bowiem dobór wyrazów, które mają taką samą liczbę sylab (a tym samym samogłosek) jak te w polskiej wersji językowej utworu. Ćwiczenie można przeprowadzać w grupach na poziomie A1/A2.

${ }^{4}$ Wskazówki dotyczące korzystania z serwisu oraz ściągania zamieszczonych tam filmów można znaleźć w artykule Rafała Maćkowiaka (2017) YouTube na lekcji języka polskiego jako obcego.

${ }^{5} \mathrm{~W}$ nawiasie podaję zagadnienie gramatyczne, które może być ćwiczone $\mathrm{z}$ wykorzystaniem tekstu danej piosenki. 
Zadanie 2. (Kolorowy wiatr)

Proszę uzupełnić tekst rzeczownikami w odpowiedniej formie tak, aby powstała nowa opowieść. Proszę pamiętać, że nowe słowa muszą mieć taką samą liczbę samogłosek, jaką mają oryginalne wyrazy.

Ty masz mnie za głupią

Lecz choć cały

Zjeździłeś wzdłuż i wszerz

I mądry jesteś tak

Że aż słów podziwu brak

Dlaczego, powiedz mi, tak mało wiesz?

Mało wiesz..

Na lądzie, gdy rozglądasz się, lądując

Chcesz mieć na własność, nawet

A ja wiem, że ten głaz ma także ..ma i zaklęty w sobie

Czy wiesz czemu wilk tak wyje w księżycowa ......?

I czemu ryś tak szczerzy rad?
Czy powtórzysz te ............, co $\mathrm{z}$ gór płyną? które kolorowy niesie wiatr , które kolorowy niesie wiatr...

Do chmur każde drzewo się pnie

Skąd .........wiedzieć masz skoro ścinasz ..........?

To nie tobie ptak się zwierza

W księżycową

Lecz ludziom wszelkich ras i wszelkich wiar

Chłonącym te co z gór płyną które kolorowy niesie wiatr.

Możesz zdobyć

Lecz to będzie tylko świat

Tylko świat!

Nie barwy, które niesie wiatr....

\subsection{WYKORZYSTANIE PIOSENEK Z REKLAM TELEWIZYJNYCH I RADIOWYCH}

Kolejnym etapem przygotowywania grupy do pracy z piosenką popularną jest stosowanie na początku zajęć rozgrzewek, które do niej nawiązują. Taka forma wprowadzająca w tok lekcji jest doskonałym rozwiązaniem zarówno dla uczniów o refleksyjnym stylu poznawczym, którzy potrzebują więcej czasu, aby zaangażować się w zadania związane $\mathrm{z}$ tematem, jak i dla tych o stylu impulsywnym, dla których konieczne jest intensywne działanie już od pierwszych minut zajęć (Siek-Piskozub 2007, s. 21). Inspiracją do skonstruowania ćwiczeń wstępnych mogą być reklamy telewizyjne wykorzystujące motywy ze znanych utworów. Najpierw warto przedstawić materiały promocyjne, w których do przeboju - w oryginale śpiewanego po angielsku - dopasowano polski tekst zachęcający do kupna danego produktu. W grupach na poziomie A2/B1 przykładem prowokującym rozmowę o pierwotnym znaczeniu tekstu piosenki oraz o tekście reklamowym stworzonym do znanej melodii może być spot sieci T-Mobile, w którym Kinga Preis 
i Tomasz Kot śpiewają adaptację utworu Simply the Best Tiny Turner. Po wstępnej analizie zadaniem uczniów jest zredagowanie własnego materiału promocyjnego w języku polskim do znanej, zagranicznej muzyki - wybranej przez siebie lub narzuconej przez lektora.

Następny etap to porównywanie treści piosenek ze spotów reklamowych wykorzystujących nasze rodzime przeboje z ich oryginalną treścią. Przykłady, którymi można się posłużyć podczas zajęć, to reklama jogurtu Bakoma Senior Active - piosenka Gwiżḋę na wszystko Mieczysława Fogga (poziom A1/A2) oraz Vita-miner z unikatową wersją Hej sokoty (poziom A2/B1). Utwory zostały zaadaptowane na potrzeby spotów reklamowych, a ich rozpoznanie wymaga znajomości nie tylko współczesnych piosenek popularnych, ale także tych z początku XX wieku.

\subsection{WYKORZYSTANIE PIOSENEK JAKO ELEMENTU SCALAJĄCEGO ZAGADNIENIA PORUSZANE PODCZAS ZAJĘĆ}

Muzyka pełni często funkcję pośrednika w porozumieniu między kulturami i pokoleniami - podobnie jak miejska lingua franca, czyli hip-hop, na co w swoim artykule uwrażliwiał Piotr Kajak (2008, s. 136). Oczywiście język subkultur nie powinien być stałym czynnikiem budującym zajęcia, jednak ważne jest przekazywanie uczniom świadomości stylistycznej, wynikającej ze zróżnicowania grup społecznych (Kajak 2005, s. 131).

Ta rozmaitość jest obecna również w kontekście gatunków muzycznych. Korzystając na lekcji z piosenek, nie można pominąć kulturowego aspektu związanego z historią muzyki. Można go wprowadzać na przykład przez wspólne oglądanie fragmentów Krajowego Festiwalu Piosenki Polskiej w Opolu. Sposobem na uwzględnienie tego zagadnienia $\mathrm{w}$ programie zajęć jest także przeprowadzenie cyklu lekcji utrwalających omawiany problem, a jednocześnie przybliżających przeboje z odmiennych okresów. Takim zestawieniem - w przypadku doskonalenia umiejętności posługiwania się zaimkami - są utwory: Z kim tak ci będzie źle jak ze mną Kaliny Jędrusik; Miasteczko cud w wykonaniu Agnieszki Osieckiej; Tylko mnie poproś do tańca Anny Jantar; Zawsze tam, gdzie ty - Lady Pank oraz Nic tu po mnie, czyli piosenka, śpiewana przez finalistę programu The Voice of Poland - Michała Szczygła. Podstawą lekcji wykorzystującej utwór muzyczny jest dwukrotne wysłuchanie go, uzupełnienie tekstu brakującymi wyrazami - w tym przypadku zaimkami - i wspólne zaśpiewanie całości. Poniżej przedstawiono przykłady zadań - dostosowane do wymienionego repertuaru - które można wykorzystać z uczniami na poziomach B i C. Stanowią one uzupełnienie pracy z utworem muzycznym, której celem jest utrwalenie umiejętności korzystania 
z zaimków w codziennych sytuacjach, takich jak opowiedzenie o danym wydarzeniu, reakcja na prośbę, wskazanie drogi lub interpretacja frazy Nic tu po mnie.

Zadanie 1. (Tylko mnie poproś do tańca)

Proszę napisać odpowiedź na prośbę Tylko mnie poproś do tańca. Proszę użyć takiej samej liczby zaimków jak w piosence. Proszę dopasować odpowiedź do melodii wybranego utworu muzycznego.

Zadanie 2. (Zawsze tam, gdzie ty) Praca w parach.

Proszę w parach narysować mapę. Proszę opowiedzieć grupie historię pod tytułem Trudny powrót. Proszę korzystać z mapy i użyć w swojej historii zaimków z piosenki.

Zadanie 3. (Nic tu po mnie) Praca w grupach.

Proszę przedstawić scenkę pod tytułem Nic tu po mnie. Proszę użyć w niej jak największej liczby zaimków. (Wygrywa grupa, która wykorzysta ich najwięcej i zrobi to bezbłędnie).

Warto zauważyć, że pracę z piosenką, nawet tą samą, można realizować na kilku poziomach, czego przykładem są poniższe zadania przygotowane w oparciu o utwór Agnieszki Osieckiej Miasteczko cud. Pierwsze z nich przeznaczone jest dla uczniów na poziomie B1, którzy znają zaimki, lecz z racji trudności, jakie powoduje ten materiał, muszą regularnie trenować ich stosowanie w praktyce.

Zadanie 1. (B1)

Proszę zamienić zaimki w tekście piosenki na wybrane rzeczowniki tak, aby występowały one we właściwym przypadku gramatycznym. Jeśli to konieczne, proszę dostosować pozostałe wyrazy tak, aby można było zaśpiewać piosenkę w nowej wersji.

Zadanie dla studentów na poziomie B2 polega na połączeniu wiedzy dotyczącej poszczególnych przypadków gramatycznych i ćwiczeniu umiejętności ich stosowania w sytuacji, kiedy wszystkie występują w jednym tekście.

Zadanie 2. (B2)

Wieloetapowe zadanie do wykonania w parach - tworzenie historii.

1) Proszę znaleźć w tekście piosenki rzeczowniki w dopełniaczu (10) i ułożyć z nimi początek opowiadania pod tytułem Cudowna przygoda.

2) Proszę zamienić się kartką z koleżanką / kolegą w ławce, a następnie dopisać rozwinięcie jej / jego przygody. Proszę użyć wyrazów (rzeczowników i zaimków osobowych) w bierniku (9).

3) Proszę wspólnie dokończyć historię. Proszę wykorzystać rzeczowniki z piosenki, które występują w miejscowniku (3), celowniku (3) i narzędniku (3).

Korzystanie z piosenek na poziomie $\mathrm{C} 1 \mathrm{i} \mathrm{C} 2$ to nie tylko poprawne zrozumienie tekstu oraz analiza obecnych w nim zagadnień gramatycznych, ale także umiejętność twórczego wykorzystania jego elementów oraz interpretacja przedstawionego w nim problemu.

Zadanie 3. (C1)

Proszę napisać odpowiedź na pytanie: Dlaczego miasteczko w piosence Agnieszki

Osieckiej określone jest jako cud? Proszę uzasadnić (250 słów). 
Zadanie 4. (C2)

Proszę ułożyć tekst piosenki zawierający rzeczownik cud oraz czasowniki, które występują w piosence w czasie przeszłym i 10 dowolnych zaimków.

\subsection{PRZYKŁAD WYKORZYSTANIA PIOSENEK W KONKRETNEJ GRUPIE KURSOWEJ ${ }^{6}$}

Przejawem strategii ludycznej - oprócz odmiennych celów nauczyciela i uczniów - jest także dobór właściwej formy rozrywki do konkretnej grupy wiekowej. Należy brać pod uwagę jej potrzeby, charakter, oczekiwania. Przykładem może być czworo repatriantów uczestniczących w kursie języka polskiego w Krakowie. Ze względu na znaczne zainteresowanie polską kulturą popularną piosenki stanowiły motyw przewodni zajęć w tej grupie. Prowokowały one do dyskusji o historii i społeczeństwie dwudziestowiecznej Polski. Szczególną estymą cieszyły się utwory Eugeniusza Bodo Umówitem się z niq na dziewiąta (godziny) oraz Ja mam czas, ja poczekam (czas przyszły). Na uwagę słuchaczy zasłużyły także piosenki nienawiązujące do tradycji dwudziestolecia jak: Byt sobie król w wykonaniu Marii Peszek (czas przeszły); Za toba pójdę jak na bal Krzysztofa Krawczyka (czas przyszły); Chodź, pomaluj mój świat zespołu 2 plus 1 (tryb rozkazujący) oraz Jesteś Starego Dobrego Małżeństwa (tryb warunkowy).

Ich wykorzystanie wymagało zwrócenia szczególnej uwagi na specyficzne potrzeby uczących się. Trudność sprawiało im szybkie wypełnianie luk, a także, w szerszej perspektywie, uzupełnianie ćwiczeń lub sporządzanie notatek oraz przepisywanie z tablicy. Lekcja z piosenką wymagała odpowiedniego sprzętu - nagrania musiały być głośne i wyraźne ze względu na kłopoty ze słuchem jednego z uczestników zajęć, a teledyski wysokiej jakości, aby dodatkowo nie męczyć wzroku silnie eksploatowanego w czasie intensywnego kursu języka. Poziom grupy oscylował między A1 a A2. Celem ćwiczeń było doskonalenie kompetencji komunikacyjnej z naciskiem na słuchanie i mówienie. Poniżej przedstawiono przykłady zadań stosowanych w trakcie zajęć.

Pierwsze ćwiczenie polegało na dopasowaniu właściwej formy godziny do pustych fragmentów tekstu. Uczniowie otrzymali odpowiednio powiększony wydruk tekstu piosenki oraz kartki z różnymi określeniami czasu. Celem zadania było skoordynowanie umiejętności słuchania i czytania. Pisanie stanowiło dla

${ }^{6}$ Uczestnicy brali udział $\mathrm{w}$ intensywnym kursie języka polskiego w miejscu zamieszkania dla repatriantów oraz ich rodzin organizowanym przez ORPEG. Grupa składała się z czterech osób - małżeństwo z Kazachstanu (mężczyzna około 70 lat i kobieta około 50 lat), kobieta z Kazachstanu około 60 lat oraz kobieta z Uzbekistanu około 50 lat. W momencie rozpoczęcia kursu mieszkali oni w Polsce od roku do trzech miesięcy. 
repatriantów dodatkowe utrudnienie i zaburzało cel ćwiczenia. Dlatego po wysłuchaniu utworu i wykonaniu zadania mieli oni odpowiednio wydłużony czas na wpisanie w luki wyrazów umieszczonych na kartkach.

Zadanie 1. (Umówitem się z nią na dziewiąta)

Proszę uzupełnić tekst godziną w odpowiedniej formie.

\begin{tabular}{c|c|c|c|c} 
dziewiątej & dziewiątą & druga & północ & trzecia \\
\hline pierwsza & ósma cztery & dziewiąta & $\begin{array}{c}\text { wpół } \\
\text { do trzeciej }\end{array}$ & siódma \\
\hline piąta & dziewiątą & ósma dziewięć & pierwsza & dziewiątą
\end{tabular}

jakaś płyta

ktoś coś czyta

To nie ważne, najważniejsza dziś jest ona

Ktoś mi wszystko dziś poplątał

Ale jedno, jedno wiem

Ref: Umówiłem się z nią na

Tak mi do niej tęskno już

Zaraz wezmę od szefa akonto

Kupię jej bukiecik róż

Potem kino, cukiernia i spacer
W księżycową jasną noc

I będziemy szczęśliwi, weseli

Aż przyjdzie ................. i nas rozdzieli

I umówię się z nią na

$\mathrm{Na}$ tak jak dziś

Jak ten czas powoli leci

Do jeszcze tyle, tyle godzin

Gdyby można zrobić czary

Ponapędzać te zegary

By ............. była już

Celem kolejnego zadania było zwrócenie uwagi słuchaczy na zakończenia czasowników w czasie przeszłym, które sprawiały im najwięcej kłopotów, ponieważ nie słyszeli różnicy między - ty a -li. Następnie uczniowie wykorzystywali te słowa w tworzeniu własnych opowieści. Dodatkową inspiracją była gra Story Cubes $^{7}$, czyli specjalne kości z obrazkami, na podstawie których układa się historie.

Zadanie 2. (Byt sobie król)

Proszę uzupełnić luki odpowiednimi końcówkami czasu przeszłego. Proszę ułożyć opowieść. Proszę wykorzystać obrazki znajdujące się na kościach z gry Story Cubes i czasowniki z piosenki.

${ }^{7}$ Popularna gra towarzyska, której celem jest ułożenie krótkiej historii na podstawie obrazków umieszczonych na plastikowych kościach. Układ ilustracji jest losowy, zależny od rzutu kośćmi. 
By... sobie król,

by... sobie paź,

i by.... też królewna,

Ży.... wśród róż, nie zna.... burz

Rzecz najzupełniej pewna.

Kocha.... ją król,

kocha.... ją paź ,

kocha.... ją oboje

i ona też kocha... ich

kocha... się we troje.
Lecz srogi los

okrutna śmierć

w udziale im przypad...

króla zjad... pies

pazia zjad... kot

królewnę myszka zjad... .

Lecz żeby ci

nie by... żal

dziecino ukochana

z cukru by... król

z piernika paź

królewna z marcepana.

\section{EFEKTY WPROWADZANIA PIOSENEK NA LEKCJACH JPJO}

Stosowanie piosenek $\mathrm{w}$ glottodydaktyce niewątpliwie ma charakter uniwersalny. Można je dopasować do tematyki poruszanej podczas zajęć zarówno w kwestii leksyki, jak i zagadnień gramatycznych. Ponadto korzystanie z takiego materiału dydaktycznego zwiększa integrację grupy i buduje wzajemne zaufanie między jej członkami oraz lektorem. W przypadku uczniów o specjalnych potrzebach edukacyjnych (na przykład u osób starszych) właściwy dobór piosenek oraz ćwiczeń gramatycznych może znacznie zwiększyć efektywność uczenia się. Dla repatriantów dodatkową zaletą takich zajęć jest budowanie ich tożsamości jako Polaków. Choć związek z ojczyzną pielęgnowali poza jej granicami, po przyjeździe czują się obcy. Zaznajomienie ich z muzyczną popkulturą sprawia, że łatwiej im odnaleźć się w społeczeństwie. Ponadto rozumienie tekstów piosenek oraz powtarzanie znajdujących się w nich słów, a następnie wspólne wykonanie utworu, dowartościowuje uczących się w kwestii poprawnego posługiwania się językiem. Nie jest to jedynie sprawność lingwistyczna, ale także dowód na integrację międzykulturową, której przejawem jest rozumienie symboliki oraz wartości właściwych dla danego społeczeństwa, czyli szeroko pojęta kompetencja lingwakulturalna (Zarzycka 2004, s. 436).

Nie bez znaczenia jest także rozwój kompetencji językowych. Tę kwestię porusza m.in. Paweł Pałasz, który zwraca uwagę nie tylko na znajomość leksyki i gramatyki, ale również na rozwój sprawności mówienia i słuchania ze zrozumieniem, co nieodzownie wiąże się z umiejętnością komunikacji (2013, s. 355). Istotne jest także uświadamianie studentom, że piosenka nie stanowi jedynie formy relaksu - ma ona konkretną funkcję w nauczaniu języka. Jest to forma, którą moż- 
na zastosować w dowolnym momencie lekcji - pod warunkiem dostosowania jej do wieku, poziomu zaawansowania grupy oraz zagadnień poruszanych na lekcji. Dodatkowym atutem jest możliwość wprowadzenia kontekstu historyczno-społecznego, a tym samym zaznajomienia $\mathrm{z}$ realiami polskiej kultury (Łaszkiewicz 2010, s. 335-336).

Na uwagę zasługuje również fakt, iż wprowadzanie materiału audio stanowi pomost między tradycyjnym nauczaniem a dydaktyką korzystającą z nowoczesnych technologii. To wstęp do wdrażania uczniów w pracę z quizami internetowymi, tablicami multimedialnymi itp. (Zarzycka 2014, s. 331).

Potwierdzeniem zalet posługiwania się piosenką jako materiałem ćwiczeniowym są argumenty teoretyczne - lingwistyczny, strukturalny i psychologiczny - przytaczane w książce pt. Muzyka i słowa. Rola piosenki w procesie przyswajania języka obcego. Autorki konfrontują wykorzystanie materiałów melicznych ze strategiami nauczania - receptywną, komunikacyjną, rekonstrukcyjną i eklektyczną. Przeprowadzona przez nie analiza dowodzi, że stosowanie piosenek jest możliwe $\mathrm{w}$ przypadku każdej $\mathrm{z}$ omawianych strategii. Ponadto zmniejsza ono stres związany z nauką języka obcego, a także stymuluje wrodzone mechanizmy odpowiedzialne za przyswajanie informacji i skutecznie motywuje do dalszej nauki (Siek-Piskozub, Wach 2006, s. 40-74). Pozostaje jedynie żywić nadzieję, że koncepcja edukacji językowej z uwzględnieniem muzyki nie zostanie zaprzepaszczona i nadal będzie się rozwijać.

\section{BIBLIOGRAFIA}

Dawidziak-Kładoczna M., 2008, Wiersze i piosenki w nauczaniu dzieci języka polskiego jako obcego, „Acta Universitatis Lodziensis. Kształcenie Polonistyczne Cudzoziemców”, t. 16, M. Witkowska-Gutkowska, B. Grochala, (red.), s. 37-48.

Dobrołowicz J., 2006, Kultura popularna nowym obszarem działania pedagogicznego: implikacje dla akademickiego kształcenia nauczycieli, „Studia Pedagogiczne. Problemy Społeczne, Edukacyjne i Artystyczne" 16, s. 151-163.

Huizinga J., 1998, Homo ludens. Zabawa jako źródto kultury, Warszawa.

Kajak P., 2005, Kilka uwag o polszczyźnie przerwy szkolnej, w: P. Garncarek (red.) Nauczanie języka polskiego jako obcego i polskiej kultury w nowej rzeczywistości europejskiej, Warszawa, s. $127-141$.

Kajak P., 2008, Hip hop - miejska linguafranca, „Postscriptum Polonistyczne”, r. 2 (2), s. 129-138.

Lipińska E., 2004, Księżyc w butonierce, Kraków.

Lipińska E., 2016, To samo stońce. Podręcznik doskonalacy sprawność rozumienia ze stuchu dla obcokrajowców na poziomie zaawansowanym, Kraków.

Łaszkiewicz M., 2010, Piosenka jest dobra na wszystko?, „Acta Universitatis Lodziensis. Kształcenie Polonistyczne Cudzoziemców”, t. 17, G. Zarzycka, G. Rudziński (red.), s. 335-341.

Maćkowiak R., 2017, YouTube na lekcjach języka polskiego jako obcego, w: R. Maćkowiak, E. Wojtczak (red.), Bogactwo językowe i kulturowe Europy w oczach Polaków i cudzoziemców 4, Łódź, s. 92-103. 
Madeja A., Morcinek-Cudak B., 2007, Polski mniej obcy, Katowice.

Majkiewicz A., Tambor J., 2006, Śpiewająco po polsku, Katowice.

Pałasz P.,2013, Piosenka popularna jako materiat dydaktyczny oraz możliwość jej wykorzystania na zajęciach lektoratowych z języka polskiego jako obcego, „Acta Universitatis Lodziensis. Kształcenie Polonistyczne Cudzoziemców”, t. 20, I. Dembowska-Wosik, E. Pałuszyńska (red.), s. 349-356.

Pfeiffer W., 2001, Nauka języków obcych. Od praktyki do praktyki, Poznań.

Rapacka-Wojtala S., 2015, Metody, strategie oraz techniki nauczania, uczenia się i zapamiętywania stosowane w procesie kształcenia kompetencji komunikacyjnej uczniów na lekcji języka obcego [online], http://cejsh.icm.edu.pl/cejsh/element/bwmeta1.element.desklight-4482eldf-d4ef -48a6-b0fc-479756a9fd24/c/art7.pdf [26.05.2018]

Seretny A., Lipińska E., 2005, ABC metodyki nauczania języka polskiego jako obcego, Kraków.

Siek-Piskozub T., 2007, Strategia ludyczna w glottodydaktyce, w: A. Surdyk (red.), Kulturotwórcza funkcja gier, t. 1, Poznań, s. 13-28.

Siek-Piskozub T., Wach A., 2006, Muzyka i słowa. Rola piosenki w procesie przyswajania języka obcego, Poznań.

Siek-Piskozub T., Wach A., 2013, Wielopłaszczyznowy charakter lekcji języka obcego, „Studia Rossica Posnaniensia”, r. 38, s. 231-243.

Słownik języka polskiego PWN, https://sjp.pwn.pl/szukaj/uczenie\%20się.html [dostęp: 26.05.2018].

Zarzycka G., 2004, Linguakultura - czym jest, jak ja badać i „otwierać”?, w: A. Dąbrowska (red.), Wrocławska dyskusja o języku polskim jako obcym, Wrocław, s. 435-443.

Zarzycka G., 2014, Media w nauczaniu języków obcych. Koncepcje teoretyczne $i$ wybrane rozwiazania metodyczne, „Acta Universitatis Lodziensis. Kształcenie Polonistyczne Cudzoziemców”, nr 21, E. Pałuszyńska, B. Grochala, I. Dembowska-Wosik, M. Wojenka-Karasek (red.), s. 321-333.

Zwierzycka-Raulinajtys A., 2007, Piosenka w nauczaniu dzieci języka obcego - zabawa czy trudność, w: A. Surdyk (red.), Kulturotwórcza funkcja gier, t. 1, Poznań, s. 99-107.

\section{Paulina Kaźmierczak}

\section{SONGS IN POLISH LANGUAGE LESSONS FOR FOREIGNERS}

Keywords: strategy, ludicity, glottodidactics, songs, repatriates

Summary. The article presents the use of songs in Polish lessons as a part of ludicity strategy. The author shows the methods of introducing students to this way of learning grammar. She presents examples of exercises which can help improve language skills. The article proves that songs are an important part of our environment and there is a need to use them as an element of the didactic process. 